\title{
Differential Susceptibility of 39 Tomato Varieties to Phytophthora infestans Clonal Lineage US-23
}

Z. R. Hansen and I. M. Small, Department of Plant Pathology and Plant-Microbe Biology, M. Mutschler, Department of Plant Breeding and Genetics, and W. E. Fry and C. D. Smart, Department of Plant Pathology and Plant-Microbe Biology, Cornell University, Ithaca, NY 14853

\begin{abstract}
Hansen, Z. R., Small, I. M., Mutschler, M., Fry, W. E., and Smart, C. D. 2014. Differential susceptibility of 39 tomato varieties to Phytophthora infestans clonal lineage US-23. Plant Dis. 98:1666-1670.

During the summers of 2012 and 2013, 39 tomato (Solanum lycopersicum) lines or varieties were evaluated for resistance to late blight in three separate field trials. In each trial, late blight was caused by field isolates of Phytophthora infestans clonal lineage US-23. Varieties with the late blight resistance genes $P h-1, P h-2, P h-3$, and $P h-2+P h-3$ were included, along with several heirloom varieties with growerreported resistance and varieties with no known resistance. All six varieties with $P h-2+P h-3$, along with NC25P, which is homozygous for $P h-3$ only, showed a high level of resistance. Plum Regal F1, which is heterozygous for $P h-3$ only, showed moderate resistance. Legend, the only variety with $P h-2$ alone, also showed moderate resistance. Three heirloom varieties, Matt's Wild Cherry, Lemon Drop, and Mr. Stripey, showed a high level of resistance comparable with that of varieties with $P h-2+P h-3$. New Yorker, possessing $P h-1$ only, showed

no resistance. Indeterminate varieties had significantly less disease than determinate varieties in two of the three trials. Overall, this study suggests that tomato varieties with both $P h-2$ and $P h-3$ can be used to effectively manage late blight caused by $P$. infestans clonal lineage US23. Varieties possessing only $P h-2$, or heterozygous for $P h-3$, were better protected than those without any late blight resistance but might still require supplemental fungicide applications, while the variety that was homozygous for $P h-3$ was highly resistant. Several heirloom varieties were also highly resistant, and the unknown mechanism of their resistance warrants further research. Finally, the plasticity observed in United States $P$. infestans populations over the past several decades necessitates continued monitoring for genetic changes within $P$. infestans that could lead to the breakdown of resistance reported here.
\end{abstract}

Late blight, caused by the oomycete Phytophthora infestans (Mont.) de Bary, is a rapidly progressing and sometimes devastating disease of tomato (Solanum lycopersicum L.). Late blight epidemics were first associated with the Irish potato famine of the mid-19th century, and have continued to cause significant economic losses to both potato and tomato. In addition to causing direct losses to tomato growers, late-blight-infected tomato can serve as a source of inoculum and contribute to the estimated $\$ 6.7$ billion in annual potato yield losses and costs of late blight control measures (14). Economic losses are attributed to direct crop loss as well as costs associated with fungicide applications. The 2009 late blight pandemic in the eastern United States illustrates not only the importance of tomato as a source of inoculum but also the vulnerability of tomato and potato crops when conditions are favorable for the disease (8).

In 2012, U.S. tomato production was valued at over $\$ 1.8$ billion (6). Recently, organic tomato production has accounted for 2 to $3 \%$ of total U.S. tomato acreage. Late blight is especially problematic in organic cropping systems where the use of synthetic fungicide, typically relied upon to manage the disease, are not permitted. Organic tomato production has increased from 3,063 acres in 2000 to 9,271 in 2011 (23). With increased organic tomato production comes an increased need for effective nonchemical control strategies to manage late blight. This benefits the tomato industry at large, because an ineffectively managed field serves as a potential inoculum source for susceptible crops nearby.

Breeding for resistance to tomato late blight began in the 1940s $(27,33)$. The dominant resistance $(R)$ gene $P h-1$ was the first to be

Corresponding author: C. D. Smart, E-mail: cds14@cornell.edu

Accepted for publication 14 May 2014.

http://dx.doi.org/10.1094/PDIS-03-14-0263-RE

(C) 2014 The American Phytopathological Society introgressed into domesticated tomato from a wild relative $(S$. pimpinellifolium). This gene conferred qualitative resistance to $P$. infestans race 0 but was rapidly overcome by novel pathogen genotypes $(4,10,11)$. The single incompletely dominant gene $P h-2$ confers partial resistance to some $P$. infestans genotypes, which resembles quantitative resistance $(21,32)$. $P h-2$ also originated in $S$. pimpinellifolium and was introduced in the 1960s (9). Ph-3, an incompletely dominant gene conferring strong resistance, was identified in the 1990s by researchers at the Asian Vegetable Research and Development Center in Taiwan (1). This gene was subsequently bred into fresh-market $(12,24)$, plum (13), and processing tomato lines $(19,20)$.

There are several examples of single $R$ genes being overcome by new pathogen genotypes. This occurs because a single $R$ gene imposes a strong selection pressure on the pathogen population, in much the same way that fungicides with a single mode of action encourage pathogen evolution toward fungicide resistance $(17,29)$ Some examples include the aforementioned $P h-1$ gene in tomato, $R$ genes for late blight resistance in potato, genes for rust resistance in wheat, and Fusarium wilt resistance in banana and watermelon $(2,16,25,27,35)$. This issue has been addressed through the implementation of gene pyramiding, or the introduction of multiple $R$ genes into individual varieties. In order for a pathogen to evade a plant's effector-triggered immune response and cause disease on a variety with multiple $R$ genes, it must avoid production of an effector recognized by the product of each specific $R$ gene $(17,18)$. This decreases the probability that a novel pathogen genotype, introduced by mutation or migration, will be able to overcome the resistance of the host with multiple $R$ genes, thereby increasing the durability of that resistance (31).

With late blight continuing to cause significant economic losses to tomato production annually, especially in the eastern United States, there is a need to determine which tomato varieties are resistant to the current strain of $P$. infestans. In order to simplify terminology, "variety" is used to refer to all experimental entries, including commercial and heirloom tomato varieties as well as 
breeding lines. The heirloom tomato varieties Lemon Drop and Mr. Stripey have grower-reported late blight resistance that had yet to be confirmed or characterized. Grower-reported resistance in Matt's Wild Cherry, another heirloom variety, was recently confirmed (28). The goal of our research was to screen 39 tomato varieties for resistance to the current predominant U.S. clonal lineage of $P$. infestans (US-23). Varieties with the late blight resistance genes $P h-2$ and $P h-3$, both alone and in combination, were evaluated along with heirloom varieties with grower-reported resistance and varieties without any known resistance.

\section{Materials and Methods}

Experimental design and transplant production. The experiment was done three times: twice in Freeville, NY (2012 and 2013) and once in Geneva, NY (2013). The experimental design was a randomized complete block with four replications. Thirty-seven tomato varieties were selected for the experiment in 2012. Two additional varieties were included in 2013 (Table 1). Varieties were chosen based on their late blight resistance genes $(P h-1, P h-2$, or $P h-3)$ or grower-reported resistance. Several susceptible control varieties were also included. Tomato plants for the Freeville experiments were seeded in 72-cell flats and placed in the greenhouse on 19 June 2012 and 2013. Tomato plants for the Geneva experiment were seeded in 72-cell flats and placed in the greenhouse on 14 May 2013.

Freeville field plot establishment. The 2012 experiment was conducted at the Cornell University Homer C. Thompson Vegeta- ble Research Farm in Freeville, NY. The soil type is Howard gravelly loam. Five seedlings per plot were transplanted directly into soil on 30 July using a waterwheel planter which delivered 21-5-20 fertilizer (Jr Peters Inc.) at a rate of $1 \mathrm{~kg} 208$ liter $^{-1}$. Plants were spaced $0.46 \mathrm{~m}$ apart with $1.37 \mathrm{~m}$ between plots, and irrigated with overhead irrigation when necessary. Rows were spaced $1.8 \mathrm{~m}$ apart. The preplant herbicides metolachlor $\left(1,169 \mathrm{ml} \mathrm{ha}^{-1}\right)$ and metribuzin $\left(387 \mathrm{ml} \mathrm{ha}^{-1}\right.$ ) were applied on 20 July 2012 to manage weeds. Monthly rainfall totals in August and September were 9.7 and $8.1 \mathrm{~cm}$, respectively.

The 2013 experiment was conducted in a field adjacent to the site of the 2012 experiment. Five seedlings per plot were transplanted directly into soil on 29 July as described above, except rows were spaced $1.4 \mathrm{~m}$ apart. Plants were irrigated with overhead irrigation when necessary. The preplant herbicides metolachlor $\left(1,169 \mathrm{ml} \mathrm{ha}^{-1}\right)$, metribuzin $\left(387 \mathrm{ml} \mathrm{ha}^{-1}\right)$, and halosulfuron $(36.5$ $\mathrm{ml} \mathrm{ha}^{-1}$ ) were applied on 26 July 2013 to manage weeds. Monthly rainfall totals in August and September were 19.8 and $7.5 \mathrm{~cm}$, respectively.

Geneva 2013 field plot establishment. The experiment was conducted at the New York State Agricultural Experiment Station in Geneva, NY. The soil type is Lima loam. Prior to transplanting in Geneva, raised beds were formed, $0.9 \mathrm{~m}$ wide and $1.8 \mathrm{~m}$ between centers, and covered with black high-density polyethylene mulch. Drip irrigation tape was laid beneath the plastic. Five seedlings per plot were transplanted on 26 June, spaced $0.5 \mathrm{~m}$ apart with $1.8 \mathrm{~m}$ between plots, using the waterwheel transplanter as

Table 1. Tomato varieties used in the experiments and their late blight resistance genes, growth habits, classes, and seed sources

\begin{tabular}{|c|c|c|c|c|}
\hline Variety & Resistance & $\begin{array}{c}\text { Growth } \\
\text { habit }\end{array}$ & Tomato class & Seed source \\
\hline New Yorker OP & Homozygous $P h-1$ & Indeterminate & Fresh market & Totally Tomatoes \\
\hline Legend OP & Homozygous $P h-2$ & Determinate & Fresh market & Tomato Growers Supply Company \\
\hline $\mathrm{NC} 25 \mathrm{P}^{\mathrm{x}}$ & Homozygous $P h-3$ & Determinate & Plum & Dilip Panthee, North Carolina State \\
\hline Plum Regal F1x & Heterozygous $P h-3$ & Determinate & Plum & Bejo Seeds \\
\hline NC1CELBR ${ }^{y, z}$ & Homozygous $P h-2+$ homozygous $P h-3$ & Determinate & Fresh market & Dilip Panthee, North Carolina State \\
\hline NC2CELBR ${ }^{y}$ & Homozygous $P h-2+$ homozygous $P h-3$ & Determinate & Fresh market & Dilip Panthee, North Carolina State \\
\hline Legend $\times$ NC1CELBR ${ }^{\mathrm{z}}$ & Homozygous $P h-2+$ heterozygous $P h-3$ & Determinate & Fresh market & Martha Mutschler-Chu, Cornell University \\
\hline Defiant PHR F1 & Heterozygous $P h-2+$ heterozygous $P h-3$ & Determinate & Fresh market & Johnny's Selected Seeds \\
\hline Mountain Magic $F 1^{z}$ & Heterozygous $P h-2+$ heterozygous $P h-3$ & Indeterminate & Cherry & Bejo Seeds \\
\hline Mountain Merit ${ }^{\mathrm{Z}}$ & Heterozygous $P h-2+$ heterozygous $P h-3$ & Determinate & Fresh market & Bejo Seeds \\
\hline Amish Paste & Unknown & Indeterminate & Plum & Totally Tomatoes \\
\hline Aunt Ginny's Purple & Unknown & Indeterminate & Fresh market & Tomato Growers Supply Company \\
\hline BHN1009 & Unknown & Determinate & Fresh market & Siegers Seed Company \\
\hline Brandywine & Unknown & Indeterminate & Fresh market & Harris Seeds \\
\hline Charger & Unknown & Determinate & Fresh market & Siegers Seed Company \\
\hline FL 8059 & Unknown & Determinate & Fresh market & Jay Scott, University of Florida \\
\hline FL 8111 & Unknown & Determinate & Fresh market & Jay Scott, University of Florida \\
\hline Florida 47 & Unknown & Determinate & Fresh market & Harris Seeds \\
\hline Golden Sweet F1 & Unknown & Indeterminate & Cherry & Tomato Growers Supply Company \\
\hline H3402 & Unknown & Determinate & Plum & Beth Gugino, The Pennsylvania State University \\
\hline H9704 & Unknown & Determinate & Plum & Beth Gugino, The Pennsylvania State University \\
\hline Heinz 1439 & Unknown & Determinate & Plum & Tomato Growers Supply Company \\
\hline Heinz H9780 & Unknown & Determinate & Plum & Eugene Miyao, University of California \\
\hline Juliet & Unknown & Indeterminate & Plum & Tomato Growers Supply Company \\
\hline Lemon drop & Unknown & Indeterminate & Cherry & Totally Tomatoes \\
\hline Matt's Wild Cherry & Unknown & Indeterminate & Cherry & Johnny's Selected Seeds \\
\hline Monsanto AB2 & Unknown & Determinate & Plum & Eugene Miyao, University of California \\
\hline Mountain Fresh Plus & Unknown & Determinate & Fresh market & Harris Seeds \\
\hline Mr. Stripey & Unknown & Indeterminate & Fresh market & Harris Seeds \\
\hline NC 84-173 & Unknown & Determinate & Plum & Martha Mutschler-Chu, Cornell University \\
\hline Primo Red & Unknown & Determinate & Fresh market & Harris Seeds \\
\hline Red Bounty & Unknown & Determinate & Fresh market & Harris Seeds \\
\hline Red Deuce & Unknown & Determinate & Fresh market & Harris Seeds \\
\hline Red Pearl & Unknown & indeterminate & Cherry & Johnny's Selected Seeds \\
\hline Rockytop & Unknown & Determinate & Fresh market & Siegers Seed Company \\
\hline Scarlet Red & Unknown & Determinate & Fresh market & Harris Seeds \\
\hline Sungold & Unknown & Indeterminate & Cherry & Johnny's Selected Seeds \\
\hline Tasti Lee & Unknown & Determinate & Fresh market & Bejo Seeds \\
\hline West Virginia $63 \mathrm{OP}$ & Unknown & Indeterminate & Fresh market & Karen Hyde, West Virginia \\
\hline
\end{tabular}

${ }^{x}$ NC25P is a parent of Plum Regal F1.

y NC1CELBR and NC2CELBR are sister lines developed from the same pedigree.

${ }^{\mathrm{z}} \mathrm{NC1CELBR}$ is a parent of Mountain Magic, Mountain Merit, as well as the Legend $\times$ NC1CELBR hybrid. 
described above. Monthly rainfall totals in August and September were 10.8 and $4.1 \mathrm{~cm}$, respectively.

Late blight inoculations. Plants in the Geneva experiment were infected via natural inoculum. Plants in the Freeville experiments were artificially inoculated with $P$. infestans US-23 in 2012 and 2013. In each of the three experiments, late blight was caused by $P$. infestans clonal lineage US-23, based on restriction fragment length polymorphism and simple sequence repeat analyses (7). Inoculum was generated with infected tomato leaves from naturally occurring late blight outbreaks in Dryden, NY and Geneva, NY. Infected tomato leaves were incubated overnight at room temperature in plastic bags containing wet paper towels to encourage pathogen sporulation. Sporulating tomato leaves were then rinsed in a beaker containing 500 to $1,000 \mathrm{ml}$ of distilled water. $P$. infestans sporangia were counted using a microscope and hemacytometer, and the suspension was diluted to a concentration of 4,000 sporangia $\mathrm{ml}^{-1}$. The spore suspension was stored at $4{ }^{\circ} \mathrm{C}$ for approximately $2 \mathrm{~h}$ prior to inoculation to encourage the release of zoospores. On the evenings of 22 August 2012, and 4 September 2013, whole plots were inoculated with $20 \mathrm{ml}$ of zoospore suspension at 4,000 sporangia $\mathrm{ml}^{-1}$ with a handheld pump sprayer. Prior to inoculation, overhead irrigation was run for approximately 30 min to ensure adequate moisture for infection.

Table 2. Area under the disease progress curve (AUDPC) values for each of the three experiments

\begin{tabular}{|c|c|c|c|}
\hline \multirow[b]{2}{*}{ Variety } & \multicolumn{3}{|c|}{ AUDPCz } \\
\hline & $\begin{array}{c}\text { Freeville } \\
2012\end{array}$ & $\begin{array}{c}\text { Freeville } \\
2013\end{array}$ & $\begin{array}{c}\text { Geneva } \\
2013\end{array}$ \\
\hline NC2CELBR & $0 \mathrm{~A}$ & $0 \mathrm{~A}$ & $4 \mathrm{~A}$ \\
\hline Mountain Merit & $0 \mathrm{~A}$ & $20 \mathrm{~A}$ & $109 \mathrm{~A}$ \\
\hline Matt's Wild Cherry & $0 \mathrm{~A}$ & $9 \mathrm{~A}$ & $2 \mathrm{~A}$ \\
\hline NC25P & $0 \mathrm{~A}$ & $12 \mathrm{~A}$ & $52 \mathrm{~A}$ \\
\hline NC1CELBR & $0 \mathrm{~A}$ & $0 \mathrm{~A}$ & $2 \mathrm{~A}$ \\
\hline Legend $\times$ NC1CELBR & NI & $0 \mathrm{~A}$ & $98 \mathrm{~A}$ \\
\hline Mountain Magic F1 & $0 \mathrm{~A}$ & $1 \mathrm{~A}$ & $6 \mathrm{~A}$ \\
\hline Lemon drop & $3 \mathrm{~A}$ & $3 \mathrm{~A}$ & $6 \mathrm{~A}$ \\
\hline Defiant PHR F1 & $20 \mathrm{~A}$ & $3 \mathrm{~A}$ & $30 \mathrm{~A}$ \\
\hline Plum Regal F1 & $123 \mathrm{~A}$ & $279 \mathrm{AB}$ & $492 \mathrm{BC}$ \\
\hline Mr. Stripey & $127 \mathrm{~A}$ & $35 \mathrm{~A}$ & $50 \mathrm{~A}$ \\
\hline Legend OP & $796 \mathrm{~B}$ & $590 \mathrm{BC}$ & $435 \mathrm{~B}$ \\
\hline Heinz 1439 & $1,220 \mathrm{C}$ & $849 \mathrm{CDE}$ & $1,011 \mathrm{FGH}$ \\
\hline Brandywine & $1,393 \mathrm{CD}$ & $967 \mathrm{DEF}$ & $901 \mathrm{EFG}$ \\
\hline Juliet & $1,506 \mathrm{CDE}$ & $1,041 \mathrm{DEF}$ & $775 \mathrm{DE}$ \\
\hline Mountain Fresh Plus & $1,511 \mathrm{CDE}$ & $900 \mathrm{CDEF}$ & $1,006 \mathrm{FGH}$ \\
\hline Red Pearl & $1,572 \mathrm{CDE}$ & $1,056 \mathrm{DEF}$ & $662 \mathrm{CD}$ \\
\hline Tasti Lee & $1,594 \mathrm{CDE}$ & $964 \mathrm{DEF}$ & 981 FGH \\
\hline Florida 47 & $1,611 \mathrm{CDE}$ & $1,038 \mathrm{DEF}$ & $1,042 \mathrm{FGH}$ \\
\hline Charger & $1,614 \mathrm{CDE}$ & $1,006 \mathrm{DEF}$ & $1,052 \mathrm{FGH}$ \\
\hline Aunt Ginny's Purple & $1,649 \mathrm{DE}$ & $814 \mathrm{CD}$ & $1,008 \mathrm{FGH}$ \\
\hline FL 8059 & $1,658 \mathrm{DE}$ & $1,029 \mathrm{DEF}$ & 1,001 FGH \\
\hline Amish Paste & $1,671 \mathrm{DE}$ & $1,069 \mathrm{DEF}$ & $970 \mathrm{FGH}$ \\
\hline Monsanto AB2 & $1,683 \mathrm{DE}$ & $1,132 \mathrm{DEF}$ & $1,084 \mathrm{GH}$ \\
\hline New Yorker OP & $1,715 \mathrm{DEF}$ & $1,167 \mathrm{EF}$ & $1,051 \mathrm{FGH}$ \\
\hline Sungold & $1,730 \mathrm{DEF}$ & $1,010 \mathrm{DEF}$ & $884 \mathrm{EF}$ \\
\hline Red Bounty & $1,752 \mathrm{DEF}$ & $1,083 \mathrm{DEF}$ & $1,002 \mathrm{FGH}$ \\
\hline Rockytop & $1,803 \mathrm{EFG}$ & $1,069 \mathrm{DEF}$ & $1,004 \mathrm{FGH}$ \\
\hline Scarlet Red & $1,824 \mathrm{EFGH}$ & $1,065 \mathrm{DEF}$ & $1,036 \mathrm{FGH}$ \\
\hline West Virginia 63 OP & $1,825 \mathrm{EFGH}$ & $1,181 \mathrm{~F}$ & $1,030 \mathrm{FGH}$ \\
\hline H9704 & 1,842 EFGHI & $1,077 \mathrm{DEF}$ & $1,125 \mathrm{H}$ \\
\hline Red Deuce & $1,844 \mathrm{EFGHI}$ & $1,067 \mathrm{DEF}$ & $1,080 \mathrm{GH}$ \\
\hline H3402 & 1,853 EFGHI & $1,108 \mathrm{DEF}$ & $1,062 \mathrm{FGH}$ \\
\hline Primo Red & $1,876 \mathrm{EFGHI}$ & $1,150 \mathrm{EF}$ & $1,068 \mathrm{FGH}$ \\
\hline Heinz H9780 & 2,096 FGHI & $1,017 \mathrm{DEF}$ & $1,063 \mathrm{FGH}$ \\
\hline BHN1009 & $2,184 \mathrm{GHI}$ & $1,029 \mathrm{DEF}$ & $990 \mathrm{FGH}$ \\
\hline NC 84-173 & NI & $941 \mathrm{DEF}$ & $1,053 \mathrm{FGH}$ \\
\hline FL 8111 & $2,229 \mathrm{HI}$ & $1,176 \mathrm{~F}$ & $1,110 \mathrm{H}$ \\
\hline Golden Sweet F1 & $2,250 \mathrm{I}$ & $1,058 \mathrm{DEF}$ & $754 \mathrm{DE}$ \\
\hline
\end{tabular}

${ }^{\mathrm{z}}$ All values are the mean of four replicates. Means followed by the same letter within each experiment are not significantly different, TukeyKramer honestly significant difference $(P<0.05)$. NI indicates Legend $x$ NC1CELBR and NC 84-173 were not included in the Freeville 2012 experiment.
Disease ratings and statistical analysis. Late blight disease severity ratings were taken as percentage of diseased tissue of entire plots with the aid of the assessment key described by James (15). Severity was rated one to two times a week throughout each experiment until the majority of susceptible plants had died from late blight. In Freeville in 2012, 11 disease severity ratings were taken between 21 August and 3 October. In Freeville in 2013, seven disease severity ratings were taken between 6 and 29 September. In Geneva in 2013, 10 disease severity ratings were taken between 16 August and 12 September.

After disease severity data were collected, the mean area under the disease progress curve (AUDPC) was calculated for each tomato variety in each experiment (5). AUDPC values were calculated using Microsoft Excel and analyzed using PROC GLIMMIX in SAS (SAS Inc.). Data for each experiment were analyzed separately using the Tukey-Kramer honestly significant difference (HSD) test to determine mean separations. Replications were considered random effects and tomato varieties were considered fixed effects.

An additional analysis was done in which tomato varieties were divided into two groups-growth habit and fruit type-to determine differences between groups. Groups were divided into subcategories and each group was analyzed separately. Growth habit was divided into two subcategories: determinate and indeterminate. Fruit type was divided into three subcategories: fresh market, plum, and cherry. Data were analyzed using PROC GLIMMIX in SAS (SAS Inc.). Mean separations were determined using the Tukey-Kramer HSD test. Replications were considered random effects and growth habit and fruit type were considered fixed effects.

\section{Results}

Disease development. In the Freeville experiments, late blight symptoms were first observed on 26 August 2012 and 4 September 2013. In Geneva, late blight symptoms were first observed on 19 August 2013. Disease progress was relatively consistent among late-blight-resistant tomato varieties across the three experiments (Table 2). In the 2012 Freeville experiment, six varieties remained late-blight free: NC2CELBR, NC1CELBR, Mountain Merit, Matt's Wild Cherry, NC25P, and Mountain Magic F1. Four varieties-Lemon Drop, Defiant PHR F1, Plum Regal F1, and Mr. Stripey - had a very small amount of disease. These varieties were still highly resistant to late blight and were statistically grouped with the late-blight free varieties. Legend OP was moderately resistant and the remaining varieties were susceptible to late blight caused by $P$. infestans US-23 (Table 2).

In the 2013 Freeville experiment, three varieties remained disease free: NC2CELBR, NC1CELBR, and the newly added Legend $\times$ NC1CELBR hybrid. The disease-free varieties were statistically grouped together with the same highly resistant varieties as in 2012. Plum Regal F1 was also statistically grouped with Legend OP. The remaining varieties were susceptible to varying degrees (Table 2).

In the 2013 Geneva experiment, none of the varieties remained disease-free (Table 2). However, the same varieties that showed a high degree of resistance in the first two experiments displayed similar results in Geneva in 2013. One exception was Plum Regal F1, which had significantly more disease than the highly resistant varieties in the 2013 Geneva experiment only.

Efficacy of resistance genes. Varieties heterozygous or homozygous for both the $P h-2$ and $P h-3(P h-2+P h-3)$ resistance genes were highly resistant to $P$. infestans US-23 in all three experiments (Tables 1 and 2). Mean AUDPC values for varieties with $P h-2+$ $P h-3$ were not significantly different from one another (Table 2). The heirloom varieties Matt's Wild Cherry, Lemon Drop, and Mr. Stripey were also highly resistant and grouped with the $P h-2+P h$ 3 varieties (Table 2). The plum line NC25P, which is homozygous for $P h-3$ only, was also highly resistant and not significantly different from $P h-2+P h-3$ varieties. Plum Regal F1, which is heterozygous for $P h-3$ only, was moderately resistant. In Freeville in 2012, 
Plum Regal F1, for which NC25P is one parent, had slightly more disease than $P h-2+P h-3$ varieties but the difference was not statistically significant. In Freeville in 2013, Plum Regal F1 was moderately resistant and grouped with $P h-2+P h-3$ varieties as well as Legend OP, which has Ph-2 only. In Geneva in 2013, Plum Regal F1 was moderately resistant and grouped with both Legend OP and 'Red Pearl', the latter of which is not known to possess any late blight resistance genes. Legend OP, which is homozygous for $P h-2$ only, was significantly less resistant to $P$. infestans US-23 than $P h$ $2+P h-3$ varieties in each of the three experiments. Legend OP had AUDPC values which fell between those of $P h-2+P h-3$ varieties and susceptible varieties in each experiment (Table 2). The hybrid of Legend $\times$ NC1CELBR was not significantly less resistant than its $P h-2+P h-3$ parent NC1CELBR but was significantly more resistant than its $P h-2$ parent Legend. New Yorker, which is homozygous for $P h-1$ only, was susceptible to $P$. infestans US-23 in all three experiments and was statistically grouped with the majority of other susceptible varieties. Several significant differences were observed among susceptible varieties in each of the three experiments. However, none of the significant differences remained consistent across all three experiments (Table 2).

Effect of tomato growth habit and class on late blight severity ratings. Resistant varieties were excluded from the analysis because there were not equal numbers of resistant varieties in each category. Resistant varieties included those with the lowest AUDPC values, up to and including Plum Regal F1 and Legend (Tables 1 and 2). Growth habit was a significant factor in Geneva in 2013, where the mean AUDPC was smaller for the indeterminate versus determinate category (Table 3 ). Fruit type was a significant factor in the analysis of susceptible varieties in Geneva 2013, where the mean AUDPC value for the cherry tomato class was significantly lower than that of the plum and fresh-market classes, which grouped together according to Tukey's HSD (Table 3 ). Neither growth habit nor class were significant factors in Freeville in 2012 or 2013.

\section{Discussion}

Late blight epidemics were successfully established in tomato variety field trials in both 2012 and 2013. The experiments contained susceptible varieties as well as varieties containing both $\mathrm{Ph}$ 2 and $P h-3$, which were highly resistant to $P$. infestans US-23. These experiments support previous reports that $P h-3$ provides qualitative or race-specific resistance $(3,22)$, and that $P h-3$ is a partially dominant allele which confers stronger resistance to $P$. infestans when it is in the homozygous condition versus the heterozygous condition. This is shown by the differences in disease severity observed in NC25P, homozygous for $P h-3$, and Plum Regal F1, heterozygous for $P h-3$. In each experiment, NC25P showed less disease than Plum Regal F1, despite the fact that both varieties contain $P h-3$ only. A caveat is that the differences observed between NC25P and Plum Regal F1 may be due to other genetic components because the varieties have different parental backgrounds. Plum Regal F1 is the F1 hybrid created by the cross of NC25P and NC30P, a breeding line not included in these experiments. It is possible that, in addition to conferring heterozygosity for the $P h-3$ allele, the cross resulted in the loss of the action of unknown recessive quantitative resistance genes possessed by NC25P.

Legend OP, homozygous for $P h-2$, was consistently less resistant than the $P h-2+P h-3$ varieties in all three experiments. Its statistical groupings varied in each experiment but its AUDPC values consistently ranked between the highly resistant varieties and the highly susceptible varieties. Our observations support existing literature indicating that $P h-2$ is an incompletely dominant gene which confers partial resistance to $P$. infestans, in this case clonal lineage US-23 $(21,22)$.

Tomato growth habit and tomato class were analyzed to determine whether differences among susceptible varieties were associated with these factors. The effect of growth habit was significant in Geneva in 2013 but not in Freeville in 2012 or 2013. The difference in the effect of growth habit observed between experiments is probably due to the speed with which disease progressed. As late blight progresses, indeterminate tomato varieties can continue to add new foliar growth on the tips of infected stems. This can even be observed on severely infected plants that are rated at $90 \%$ or greater disease severity. Determinate varieties do not display this characteristic. As a result, a more pronounced effect of growth habit is observed when disease progresses slowly and more disease severity ratings are taken compared with when disease progresses rapidly and fewer disease severity ratings are taken. The Freeville 2013 experiment had the fastest disease progress of the three experiments and the fewest disease severity ratings. In that experiment, there was almost no difference in the mean AUDPC value between determinate and indeterminate susceptible varieties. In Geneva in 2013, the disease progressed more slowly and more disease severity ratings were taken, allowing more time to observe the effect of indeterminate regrowth. This may also account for the numerically higher mean AUDPC for determinate susceptible varieties observed in Freeville in 2012 compared with indeterminate susceptible varieties, although that difference was not significant (Tukey's HSD, $P=0.17$ ). Additionally, several studies have indicated that the dominant self-pruning allele, which confers an indeterminate growth habit, is linked to quantitative late blight resistance $(26,34)$. However, it is difficult to determine whether the observed effect is truly due to host resistance or is a result of indeterminate regrowth, as previously discussed (30).

Similarly, it was thought that harvest index, or the ratio between fruit weight and total plant biomass at the time of harvest, might affect the disease ratings of late-blight-susceptible tomato varieties. Varieties with a high harvest index put little energy into foliar growth once fruit development is occurring. On the other hand, varieties with a low harvest index will continue to put energy into both foliar and fruit growth simultaneously. Tomato plants of the plum or processing classes tend to be highly branched and strongly determinate, and have a high harvest index whereas most cherry tomato plants tend to be indeterminate and have a low harvest index. Fresh-market tomato plants may either be of indeterminate or determinate growth habits. In general, fresh-market tomato plants are less highly branched than plum or processing tomato plants and have harvest indices that are variable but generally less than plum or processing tomato. Tomato class was a significant factor among susceptible varieties in Geneva in 2013, where the mean AUDPC for susceptible cherry varieties was lower than that of plum and fresh-market varieties. This result was not observed in either of the Freeville experiments. In fact, in Freeville in 2012, the cherry category had the highest mean AUDPC, although it was not significantly different from the fresh-market and plum categories. These inconsistent and somewhat contradictory results do not allow us to draw meaningful conclusions about the effect of tomato class on late blight disease severity ratings.

Table 3. Growth habit and fruit type analyses excluding resistant varieties

\begin{tabular}{lccc}
\hline & \multicolumn{3}{c}{ Mean AUDPC $^{\mathbf{y}}$} \\
\cline { 2 - 4 } Variable $^{\mathbf{z}}$ & $\begin{array}{c}\text { Freeville } \\
\mathbf{2 0 1 2}\end{array}$ & $\begin{array}{c}\text { Freeville } \\
\mathbf{2 0 1 3}\end{array}$ & $\begin{array}{c}\text { Geneva } \\
\mathbf{2 0 1 3}\end{array}$ \\
\hline Growth habit & & & \\
Indeterminate $(n=11)$ & $1,701 \mathrm{~A}$ & $1,040 \mathrm{~A}$ & $893 \mathrm{~A}$ \\
Determinate $(n=18)$ & $1,776 \mathrm{~A}$ & $1,039 \mathrm{~A}$ & $1,043 \mathrm{~B}$ \\
$P$ value & 0.168 & 0.959 & $<0.0001$ \\
Tomato class & & & \\
Plum $(n=8)$ & $1,696 \mathrm{~A}$ & $1,029 \mathrm{~A}$ & $1,018 \mathrm{~B}$ \\
Fresh market $(n=16)$ & $1,755 \mathrm{~A}$ & $1,044 \mathrm{~A}$ & $1,023 \mathrm{~B}$ \\
Cherry $(n=5)$ & $1,851 \mathrm{~A}$ & $1,041 \mathrm{~A}$ & $766 \mathrm{~A}$ \\
$P$ value & 0.229 & 0.899 & $<0.0001$ \\
\hline
\end{tabular}

${ }^{y}$ Means in each column followed by the same letter within the growth habit grouping or within the fruit type grouping are not significantly different according to Tukey-Kramer honestly significant difference $(P<0.05)$.

${ }^{\mathrm{z}}$ In Freeville in 2012, 17 determinate varieties and 7 plum varieties were planted ('NC 84-173' was not included). $P$ value indicates probability that means are not significantly different $(F$ test). 
Our results show that, over two seasons, varieties with tomato late blight resistance genes $P h-2$ and $P h-3$ had a high level of protection against $P$. infestans US-23, while the majority of varieties (which did not have either $P h-2$ or $P h-3$ ) were susceptible. The variety containing the resistance gene $P h-l$ was also susceptible. The $R$ gene $P h-2$ alone provides modest resistance, slows late blight epidemics, and may allow growers to reduce the number of fungicide applications depending on the level of disease pressure. Similarly, the $P h-3$ gene, when heterozygous, provided moderate resistance, with a higher level of resistance in the variety that was homozygous for $P h-3$. This finding supports that $P h-3$ is a partially dominant gene. Varieties with both $P h-2$ and $P h-3$ were consistently highly resistant to $P$. infestans US-23. The heirloom varieties Matt's Wild Cherry, Lemon Drop, and Mr. Stripey were all resistant to late blight in this study, and it would be interesting to identify the mechanisms underlying this resistance. Growers now have several options for tomato varieties that are resistant to the clonal lineage that has been most common over the past several seasons, and the presence of two resistance genes in many of the varieties may delay the occurrence of resistance-breaking strains of the pathogen.

\section{Acknowledgments}

We thank H. Lange for technical assistance. The project was funded by the United States Department of Agriculture Agriculture and Food Research Initiative Competitive Grants Program Grant 2011-68004-30154.

\section{Literature Cited}

1. AVDRC. 1995. AVRDC 1994 Progress Report. Shanhua, Tainan, Taiwan, ROC.

2. Bradshaw, J. E., Bryan, G. J., Lees, A. K., McLean, K., and SolomonBlackburn, R. M. 2006. Mapping the R10 and R11 genes for resistance to late blight (Phytophthora infestans) present in the potato (Solanum tuberosum) R-gene differentials of Black. TAG. Theor. Appl. Genet. 112:744751.

3. Chen, C., Sheu, Z., and Wang, T. 2008. Host specificity and tomato-related race composition of Phytophthora infestans isolates in Taiwan during 2004 and 2005. Plant Dis. 92:751-755.

4. Conover, R. A., and Walter, J. M. 1953. The occurrence of a virulent race of Phytophthora infestans on late blight resistant tomato stocks. Phytopathology 43:344-345.

5. Cooke, B. M., Jones, D. G., and Kaye, B., eds. 2006. The Epidemiology of Plant Diseases, Second. Springer, Dordrecht, The Netherlands.

6. Crop Values 2012 Summary. 2013. United States Dep. Agric. Natl. Agric. Stat. Serv. Online publication. http://usda01.library.cornell.edu/usda/nass/ CropValuSu//2010s/2013/CropValuSu-02-15-2013.pdf

7. Danies, G., Small, I. M., Myers, K., Childers, R., and Fry, W. E. 2013. Phenotypic characterization of recent clonal lineages of Phytophthora infestans in the United States. Plant Dis. 97:873-881.

8. Fry, W. E., McGrath, M. T., Seaman, A., Zitter, T. A., McLeod, A., Danies, G., Small, I. M., Myers, K., Everts, K., Gevens, A. J., Gugino, B. K., Johnson, S. B., Judelson, H., Ristaino, J., Roberts, P., Secor, G., Seebold, K., Snover-Clift, K., Wyenandt, A., Grunwald, N. J., and Smart, C. D. 2013. The 2009 late blight pandemic in Eastern USA — causes and results. Plant Dis. 97:296-306.

9. Gallegly, M. E. 1960. Resistance to the late blight fungus in tomato. Pages 113-135 in: Proceedings, Plant Science Seminar, Campbell Soup Co., Camden, $\mathrm{NJ}$

10. Gallegly, M. E. 1968. Genetics of pathogenicity of Phytophthora infestans. Annu. Rev. Phytopathol. 6:375-396.

11. Gallegly, M. E., and Marvel, M. E. 1955. Inheritance of resistance to tomato race 0 of Phytophthora infestans. Phytopathology 45:103-109.

12. Gardner, R. G., and Panthee, D. R. 2010. NC 1 CELBR and NC 2 CELBR: Early blight and late blight-resistant fresh market tomato breeding lines.
HortScience 45:975-976.

13. Gardner, R. G., and Panthee, D. R. 2010. "Plum Regal" fresh-market plum tomato hybrid and its parents, NC 25P and NC 30P. HortScience 45:824825 .

14. Haverkort, A. J., Boonekamp, P. M., Hutten, R., Jacobsen, E., Lotz, L. A. P., Kessel, G. J. T., Visser, R. G. F., and van der Vossen, E. A. G. 2008. Societal costs of late blight in potato and prospects of durable resistance through cisgenic modification. Potato Res. 51:47-57.

15. James, W. C. 1971. An illustrated series of assessment keys for plant diseases, their preparation and usage. Can. Plant Dis. Surv. 51:39-65.

16. Johnson, R. 1992. Reflections of a plant pathologist on breeding for disease resistance, with emphasis on yellow rust and eyespot of wheat. Plant Pathol 41:239-254.

17. Jones, J. D. G., and Dangl, J. L. 2006. The plant immune system. Nature 444:323-329.

18. Kamoun, S., and Smart, C. D. 2005. Late blight of potato and tomato in the genomics era. Plant Dis. 89:692-699.

19. Kim, M., and Mutschler, M. A. 2005. Transfer to processing tomato and characterization of late blight resistance derived from Solanum pimpinellifolium L. L3708. J. Am. Soc. Hortic. Sci. 130:877-884.

20. Kim, M., and Mutschler, M. A. 2006. CULBPT-A46 and CULBPT-A48 series of late blight resistant processing tomato breeding lines. HortScience 41:263-265.

21. Moreau, P., Thoquet, P., Olivier, J., Laterrot, H., Grimsley, N., and Biologie, L. De. 1998. Genetic mapping of Ph-2, a single locus controlling partial resistance to Phytophthora infestans in tomato. Mol. Plant-Microbe Interact. 11:259-269.

22. Nowicki, M., Foolad, M. R., Nowakowska, M., and Kozik, E.. 2012. Potato and tomato late blight caused by Phytophthora infestans: An overview of pathology and resistance breeding. Plant Dis. 96:4-17.

23. Organic Production: Overview. 2013. United States Dep. Agric. Econ. Res. Serv. Online publication. http://www.ers.usda.gov/data-products/organicproduction.aspx\#.UtRMy55dX_F

24. Panthee, D. R., and Gardner, R. G. 2010. "Mountain Merit": A late blightresistant large-fruited tomato hybrid. HortScience 45:1547-1548.

25. Ploetz, R. C. 2006. Fusarium wilt of banana is caused by several pathogens referred to as Fusarium oxysporum f. sp. cubense. Phytopathology 96:653656.

26. Pnueli, L., Carmel-Goren, L., Hareven, D., Gutfinger, T., Alvarez, J., Ganal, M., Zamir, D., and Lifschitz, E. 1998. The SELF-PRUNING gene of tomato regulates vegetative to reproductive switching of sympodial meristems and is the ortholog of CEN and TFL1. Development 125:1979-1989.

27. Richards, M. C., and Barratt, R. W. 1946. A partial survey of the genus Lycopersicon for resistance to Phytophthora infestans. Plant Dis. Rep. 30:16-20.

28. Seidl, A. C., Jordan, S. A., and Gevens, A. J. 2014. Novel resistance in heirloom tomatoes and effectiveness of resistance in hybrids to Phytophthora infestans US-22, US-23, and US-24 clonal lineages. Plant Dis. 98:761-765.

29. Sierotzki, H., and Scalliet, G. 2013. A review of current knowledge of resistance aspects for the next-generation succinate dehydrogenase inhibitor fungicides. Phytopathology 103:880-887.

30. Smart, C. D., Tanksley, S. D., Mayton, H., and Fry, W. E. 2007. Resistance to Phytophthora infestans in Lycopersicon pennellii. Plant Dis. 91:1045-1049.

31. Tan, M. Y. A., Hutten, R. C. B., Visser, R. G. F., and van Eck, H. J. 2010 The effect of pyramiding Phytophthora infestans resistance genes R Pimcd1 and R Pi-ber in potato. TAG. Theor. Appl. Genet. 121:117-125.

32. Turkensteen, L. 1973. Partial Resistance of Tomatoes Against Phytophthora infestans, the Late Blight Fungus. Institute for Phytopathological Research, Wageningen, The Netherlands.

33. Walter, J. M., and Conover, R. A. 1952. Hereditary resistance to late blight of tomato. Phytopathology 42:197-199.

34. Zhang, L. P., Khan, A., Nino-Liu, D., and Foolad, M. R. 2002. A molecular linkage map of tomato displaying chromosomal locations of resistance gene analogs based on a Lycopersicon esculentum $\times$ Lycopersicon hirsutum cross. Genome 46:133-146.

35. Zhou, X. G., Everts, K. L., and Bruton, B. D. 2010. Race 3, a new and highly virulent race of Fusarium oxysporum $\mathrm{f}$. sp. niveum causing Fusarium wilt in watermelon. Plant Dis. 94:92-98. 